\title{
The social determinants of knowledge and perception on pulmonary tuberculosis among females in Jakarta, Indonesia
}

\author{
Ahmad Fuady, ${ }^{1,2}$ Trevino A. Pakasi, ${ }^{1}$ Muchtaruddin Mansyur ${ }^{1}$ \\ ${ }^{1}$ Department of Community Medicine, Faculty of Medicine, Universitas Indonesia, Jakarta, Indonesia \\ ${ }^{2}$ Institute of Health Policy and Management, Erasmus University Rotterdam, The Netherlands
}

\begin{abstract}
Abstrak
Latar belakang: Indonesia belum berhasil mengatasi masalah tuberkulosis dengan angka prevalensi dan insidens yang masih tinggi. Jakarta, ibukota Indonesia dengan populasi yang besar dan angka tuberkulosis yang tinggi, memiliki karakteristik tersendiri dalam permasalahan tuberkulosis. Studi ini bertujuan mendapatkan determinan sosial terhadap tingkat pengetahuan dan persepsi masyarakat urban terkait tuberkulosis paru.
\end{abstract}

Metode: Studi ini melibatkan 2.323 sampel secara acak di Jakarta selama Februari-Mei 2011. Kuesioner disebar untuk menilai pengetahuan dan persepsi responden terhadap tuberkulosis paru. Tingkat pengetahuan dikategorikan menjadi 'buruk' dan 'baik'. Persepsi mengenai tuberkulosis diukur dengan menilai apakah responden mempersepsikan tuberkulosis sebagai penyakit yang memalukan dan akan dikucilkan.

Hasil: Mayoritas responden (88,7\%) memiliki tingkat pengetahuan yang baik mengenai tuberkulosis, tetapi kesalahan persepsi terhadap tuberkulosis masih tinggi (45,9\%). Tingkat pendidikan mempengaruhi tingkat pengetahuan tuberkulosis. Semakin tinggi tingkat pendidikan, semakin rendah risiko kekurangan pengetahuan. Persepsi mengenai tuberkulosis ditentukan oleh pendapatan keluarga dan tingkat pendidikan. Tingginya tingkat pendapatan keluarga dan pendidikan merupakan faktor protektif terhadap mispersepsi mengenai tuberkulosis sebagai penyakit yang memalukan dan kecenderungan untuk mengucilkan pasien tuberkulosis.

Kesimpulan: Masyarakat urban Jakarta memiliki tingkat pengetahuan tuberkulosis yang baik, namun hal tersebut tidak serta merta membuat masyarakat mempersepsikan tuberkulosis secara tepat. Usia, tingkat pendidikan dan memiliki asuransi kesehatan menentukan tingkat pengetahuan, sedangkan persepsi mengenai tuberkulosis lebih banyak dipengaruhi oleh tingkat pendidikan dan pendapatan keluarga. Program pengendalian tuberkulosis harus mempertimbangkan determinan sosial tersebut sebelum membuat strategi pengendalian yang komprehensif.

\begin{abstract}
Background: Indonesia has not resolved tuberculosis burden since its prevalence and incidence has remained high. As the capital of Indonesia with a large population and a high number of tuberculosis cases, Jakarta has a distinctive condition of tuberculosis burden. This study aimed to obtain social determinants of knowledge and perception of pulmonary tuberculosis in an urban community.
\end{abstract}

Methods: This study used 2,323 samples taken by random sampling in Jakarta during February-May 2011. Questionnaires were delivered to assess respondents' knowledge and perception about pulmonary tuberculosis. Levels of knowledge were categorized into 'poor' and 'good'. Perceptions about tuberculosis were measured by whether respondents perceived tuberculosis as a humiliating disease and a shunned disease.

Results: Most respondents (88.7\%) had good level of knowledge about tuberculosis, but misperception remained high $(45.9 \%)$ in the community. Education level determined level of knowledge. The higher the education level the lower the risk of lack of knowledge. Tuberculosis perceptions were determined by family income and education level. Higher family income and education level were protective factors of misperception about tuberculosis as a humiliating disease and tendency to shun tuberculosis patients.

Conclusion: People in urban area of Jakarta have good level of knowledge about tuberculosis, but it does not necessarily lead to proper perception of tuberculosis. Age, education level and having health insurance determined level of knowledge, while tuberculosis perceptions were determined much more by education level and family income. Tuberculosis control program should consider these determinants prior to developing a comprehensive strategy.

Keywords: knowledge, perception, pulmonary tuberculosis, social determinants of health 
Tuberculosis (TB) has remained a major global health issue for almost two decades including in Indonesia. Carried out since 1995, ${ }^{1}$ directly observed treatment short course (DOTS) strategy has not been able to overcome TB problems in Indonesia. Indonesia's rank for TB prevalence has declined, but the number of TB prevalence and incidence has remained high.,3 World Health Organization (WHO) reported that estimated TB prevalence and incidence in Indonesia were still 690,000 and 450,000, respectively in 2010, with 64,000 mortality cases per year. ${ }^{2}$ In 2004,17 out of 33 provinces had higher TB prevalence than national number, ${ }^{4}$ and the number only reduced to 12 out of 33 provinces in $2010 .^{3}$

Even though medical interventions are the main global strategy, controlling TB also requires social, economic and environmental interventions as it is considered as "social disease". ${ }^{5}$ Poverty and low economic status as causes of increasing risk of TB may remain unclear, but the higher risk of TB among people in low economic status may be largely affected by the greater exposure to some risk factors of TB. Currently, DOTS program mainly focuses on curative perspective and give limited concern on public health and prevention issue. Whereas, strengthening preventive efforts in the community is imperative including protection of uninfected, healthy people in community.

TB-burdened countries like Indonesia require both good quality of health care services and community involvement. Some considerable challenges, such as delayed care seeking and poor treatment compliance, ${ }^{6,7}$ are resulted from limited community involvement in TB control program. TB programs within community are important to reduce risk infection and decline TB incidence in community. Program should modify some factors such as poor knowledge of $\mathrm{TB}^{6,8}$ and stigmatization ${ }^{7}$ in community which lead to delayed seeking care ${ }^{8,9}$ and poor adherence to treatment. Otherwise, increasing number of delayed treatment, high number of untreated cases, low cure rate, increasing number of mortality, wide spread in population, and increasing number of TB multi-drugs resistances (MDR) remain unresolved. ${ }^{10}$ Therefore, recognizing sociodemographic determinants of TB knowledge and perception in community is required.

Urban slum area is related to the high prevalence of TB. ${ }^{11}$ Jakarta, Indonesia's capital, is a highly populated urban area of Indonesia which has a distinctive condition of TB burden and a wide variety of community. It is necessary to analyze underlying problems before developing further strategy to sustain existing achievements and address remaining constraints and challenges. ${ }^{12}$ Despite its large access to both public and private health care services, Jakarta's TB prevalence is higher than national prevalence. ${ }^{3}$ Plausible factors underlying this problem, instead of availability of health care services, are social determinants. This study aims to obtain social determinants of community knowledge and perception of pulmonary TB.

\section{METHODS}

We carried out a cross-sectional study during February-May 2011 in Jakarta. As TB prevalence is higher in slum and densely area, ${ }^{11,13}$ we chose the 11 most densely villages in East Jakarta that were Bidara Cina, Pisangan Baru, Cipinang Cempedak, Kampung Melayu, Utan Kayu Utara, Malaka Sari, Utan Kayu Selatan, Palmeriam, Balimester, Kayu Manis, and Cipinang. We involved 2408 households as samples, taken by random sampling in the village, proportionally to the population density. Respondents were female of each household member who signed informed consent before the beginning of the study. We chose female as respondents since they may may provide reality in community where females are person-in-charge in households during working hours. Moreover, in Indonesia, they are also the most possible persons carrying household members to health services and attending health promotion program either in community or health services.

Since Jakarta is the main destination of urbanization, people move rapidly, some of them stay illegally, and live in slum and densely area. These conditions raised problems in data registration. We applied a point random sampling using geographic information system (GIS) supported by Arc View and Google Earth program ${ }^{14-18}$ instead of using population data from village offices, in order to tackle its possible poor validity and reliability. We spread points in Google Earth map and marked it by geographical positioning system (GPS) point. Interviewers visited the closest household to the point in the map with GPS tools support. When the closest household was unable to follow the study, interviewers would look for other households living around within a maximum distance of 50 meters. They who approved to follow the study were marked as respondents of the study. 
Before the study, we validated a questionnaire and trained interviewers to undertake interviews. Variables of socio-demographic determinants included in this study were sex, age, education level, family incomes, residence status, having health saving and having (type of) health insurances. The outcomes variables were TB knowledge and perception about $\mathrm{TB}$ as a humiliating disease and a shunned disease. The questions are provided in table 1.

Table 1. Questions asked to respondents

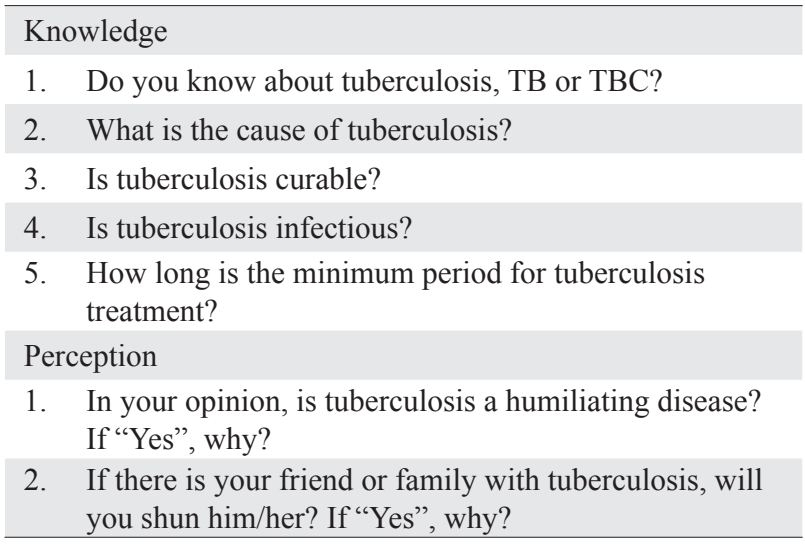

With $8.3 \%$ TB prevalence, ${ }^{4} 5 \%$ precision and alpha $=5 \%$, a minimum of 117 household are required in each sub-district. A number of 2408 household was sufficient, compared to the minimum samples required. The data are analyzed using SPSS 15. Demographic and outcome data were summarized into frequencies and percentages. The knowledge of TB was assessed by scoring with interval $0-25$ then categorized into 'poor' (0-14) and 'good' (15-25). We explored the exposure of social characteristics and outcome variables by univariate analysis. Using two-sided test, the difference is considered significant if $p<0.05$ in bivariate analysis. We included potential determinants of outcome variables at bivariate analysis $(p<0.25)$ to binary logistic and multinomial regression model.

The Ethical Committee of Faculty of Medicine Universitas Indonesia and Cipto Mangunkusumo Hospital, Indonesia approved this study prior to implementation.

\section{RESULTS}

\section{Characteristics of respondents}

We sampled respondents proportionally from 11 villages with a range of $2.2-17.2 \%$ per village. From the total of 2,408 interviewed respondents within 11 villages in Jakarta, we analyzed 2,323 (96.5\%) data of female respondents. Majority of respondents were elderly, not-working females, with $35.4 \%$ female respondents above 50 years old and $68.1 \%$ unemployed females. Fifty (3.0\%) respondents were temporary workers and foreign.

Majority of respondents' family (72.8\%) had monthly income higher than IDR 1,300,000 (USD 134) which was Jakarta's monthly regional minimum payment in 2011 and can easily access health care services (92.0\%). However, most respondents were not covered by either health insurances (58.8\%) or health saving (93.7\%). More than half respondents $(52.9 \%)$ were completely uncovered by both of health insurances and health saving. Only $4 \%$ of uninsured households prepared health savings to cover their health expenses (Table 2).

Table 2. Characteristics of respondents $(n=2,323)$

\begin{tabular}{|c|c|c|}
\hline Characteristics & $\mathrm{n}$ & $\%$ \\
\hline \multicolumn{3}{|l|}{ Age } \\
\hline$<20$ year old & 13 & 0.6 \\
\hline 20 - 30 year old & 215 & 9.3 \\
\hline 30 - 40 year old & 582 & 25.1 \\
\hline $40-50$ year old & 690 & 29.7 \\
\hline$>50$ year old & 823 & 35.4 \\
\hline \multicolumn{3}{|l|}{ Education level } \\
\hline Not graduated elementary school & 178 & 7.7 \\
\hline Elementary and secondary school & 931 & 40.1 \\
\hline High school & 995 & 42.8 \\
\hline University or higher & 219 & 9.4 \\
\hline \multicolumn{3}{|l|}{ Family income } \\
\hline$<$ IDR $1,300,000$ & 631 & 27.2 \\
\hline IDR $1,300,000-2,599,000$ & 870 & 37.5 \\
\hline IDR 2,600,000 - 5,400,000 & 629 & 27.1 \\
\hline$>$ IDR $5,400,000$ & 193 & 8.3 \\
\hline \multicolumn{3}{|l|}{ Residence status } \\
\hline Permanent resident & 2,273 & 97.8 \\
\hline Temporary workers and foreign & 50 & 2.2 \\
\hline \multicolumn{3}{|l|}{ Having health saving } \\
\hline Yes & 147 & 6.3 \\
\hline No & 2,176 & 93.7 \\
\hline \multicolumn{3}{|l|}{ Having health insurance } \\
\hline Askes & 287 & 12.4 \\
\hline Askeskin/Jamkesmas & 248 & 10.7 \\
\hline Jamsostek & 250 & 10.8 \\
\hline Other insurance & 172 & 7.4 \\
\hline No insurance & 1,366 & 58.8 \\
\hline
\end{tabular}

IDR: Indonesian Rupiah, Askes: Asuransi Kesehatan (health insurance for state civil servants), Jamkesmas: Jaminan Kesehatan Masyarakat (social health insurance for poor people), Jamsostek: Jaminan Kesehatan Sosial (health insurance for registered formal workers) 
Most respondents (88.7\%) had the good level of knowledge while the remaining $(11.3 \%)$ was lacked of knowledge $(5.2 \%)$. Despite having good level of knowledge, $45.9 \%$ out of respondents remained perceiving TB as humiliating disease while only $23.1 \%$ of respondents perceived that they would shun TB patients.

Table 3. Respondents' level of knowledge and perception $(\mathrm{n}=2,323)$

\begin{tabular}{lcc}
\hline \multicolumn{1}{c}{ Characteristics } & $\mathrm{n}$ & $\%$ \\
\hline $\begin{array}{l}\text { Level of knowledge } \\
\quad \text { Good }\end{array}$ & 2,060 & 88.7 \\
$\quad$ Poor & 263 & 11.3 \\
Perceiving TB as a humiliating disease & & \\
$\quad$ Yes & 1,066 & 45.9 \\
$\quad$ No & 1,257 & 54.1 \\
\hline $\begin{array}{l}\text { Perceiving TB as a shunned disease } \\
\text { Yes }\end{array}$ & 537 & 23.1 \\
$\quad$ No & 1,786 & 76.9 \\
\hline
\end{tabular}

\section{Social determinants of TB knowledge}

Social variables, except residence status and having health saving, were related to level of knowledge of TB with $p<0.05$. We included age, education level, family income, and type of health insurance into a multivariable binary regression analysis $(\mathrm{aOR}$, CI $95 \%$, p). This study found that those with age $>$ 50 years old was protective factor to have good TB knowledge, or a risk factor to poor TB knowledge compared to those with age of under 20 years old $(0.786,0.477-0.954,0.026)$. This study also found that those with education level of elementary and secondary school tend to have good TB knowledge (7.607, 3.299-17.540, < 0.001), compared to those had not graduated elementary school. Respondents with education level of high school also tend to have good TB knowledge despite being lower than those with basic education level (2.800, 1.300-6.034, 0.009). Another social determinant was having Askes as health insurance $(2.573,1.101-6.010,0.029)$.

Table 4. Social determinants of TB knowledge

\begin{tabular}{|c|c|c|c|c|c|c|c|}
\hline \multirow{2}{*}{ Characteristics } & \multicolumn{2}{|c|}{ Good } & \multicolumn{2}{|c|}{ Poor } & \multirow{2}{*}{$\mathrm{p}$} & \multirow{2}{*}{$\mathrm{aOR}$} & \multirow{2}{*}{$95 \% \mathrm{CI}$} \\
\hline & $\mathrm{n}$ & $\%$ & $\mathrm{n}$ & $\%$ & & & \\
\hline \multicolumn{8}{|l|}{ Age } \\
\hline$<20$ year old & 10 & 0.5 & 3 & 1.1 & 0.057 & 1.000 & \\
\hline 20-30 year old & 191 & 9.3 & 24 & 9.1 & 0.287 & 2.218 & $0.544-8.316$ \\
\hline $30-40$ year old & 533 & 25.9 & 49 & 18.6 & 0.490 & 1.194 & $0.722-1.977$ \\
\hline $40-50$ year old & 630 & 30.6 & 60 & 22.8 & 0.209 & 0.786 & $0.535-1.147$ \\
\hline$>50$ year old & 696 & 33.8 & 127 & 48.3 & 0.026 & 0.786 & $0.477-0.954$ \\
\hline \multicolumn{8}{|l|}{ Family income } \\
\hline$<$ IDR $1,300,000$ & 509 & 24.7 & 122 & 46.4 & 0.001 & 1.000 & \\
\hline IDR $1,300,000-2,599,000$ & 775 & 37.6 & 95 & 36.1 & 0.073 & 1.925 & $0.942-3.933$ \\
\hline IDR $2,600,000-5,400,000$ & 593 & 28.8 & 36 & 13.7 & 0.413 & 1.345 & $0.662-2.732$ \\
\hline$>$ IDR 5,400,000 & 183 & 8.9 & 10 & 3.8 & 0.705 & 0.866 & $0.411-1.825$ \\
\hline \multicolumn{8}{|l|}{ Education level } \\
\hline Not graduated elementary school & 118 & 5.7 & 60 & 22.8 & $<0.001$ & 1.00 & \\
\hline Elementary and secondary school & 791 & 38.4 & 140 & 53.2 & $<0.001$ & 7.607 & $3.299-17.540$ \\
\hline High school & 940 & 45.6 & 55 & 20.9 & 0.009 & 2.800 & $1.300-6.034$ \\
\hline University or higher & 211 & 10.2 & 8 & 3.0 & 0.644 & 1.210 & $0.552-2.611$ \\
\hline \multicolumn{8}{|l|}{ Health insurance } \\
\hline No insurance & 1,177 & 57.1 & 189 & 71.9 & 0.006 & 1.000 & \\
\hline Askes & 271 & 13.2 & 16 & 6.1 & 0.029 & 2.573 & $1.101-6.010$ \\
\hline Askeskin/Jamkesmas & 208 & 10.1 & 40 & 15.2 & 0.544 & 1.354 & $0.509-3.600$ \\
\hline Jamsostek & 238 & 11.6 & 12 & 4.6 & 0.188 & 1.856 & $0.739-4.660$ \\
\hline Other insurance & 166 & 8.1 & 6 & 2.3 & 0.666 & 1.252 & $0.451-3.471$ \\
\hline
\end{tabular}

aOR: Adjusted odds ratio, IDR: Indonesian Rupiah, Askes: Asuransi Kesehatan (health insurance for state civil servants), Jamkesmas: Jaminan Kesehatan Masyarakat (social health insurance for poor people), Jamsostek: Jaminan Kesehatan Sosial (health insurance for registered formal workers) 


\section{Social determinants of TB perception}

A multivariable binary regression model showed that perception of TB as humiliating disease was related to family income and education level. The higher family income and the higher education level were protective factors of misperception about TB. Those having family income higher than IDR 2,599,000 had a lower the risk to perceive TB as a humiliating disease. This study revealed similar result for those having education level more than elementary school (Table 5).

Given $23.1 \%$ of respondents perceiving that they would shun TB patients from community, their perceptions were related to family income and education level. In a multivariable binary regression analysis, respondents with higher family income and education level had lower risk to misperception of shunning TB patients (Table 6).

Table 5. Social determinants of perceiving TB as humiliating disease

\begin{tabular}{|c|c|c|c|c|c|c|c|}
\hline \multirow{2}{*}{ Characteristics } & \multicolumn{2}{|c|}{ Yes } & \multicolumn{2}{|c|}{ No } & \multirow{2}{*}{$\mathrm{p}$} & \multirow{2}{*}{$\mathrm{aOR}$} & \multirow{2}{*}{$95 \% \mathrm{CI}$} \\
\hline & $\mathrm{n}$ & $\%$ & $\mathrm{n}$ & $\%$ & & & \\
\hline \multicolumn{8}{|l|}{ Family income } \\
\hline$<$ IDR $1,300,000$ & 291 & 27.3 & 340 & 27.0 & 0.089 & 1.00 & \\
\hline IDR $1,300,000-2,599,000$ & 420 & 39.4 & 450 & 35.8 & 0.193 & 0.791 & $0.555-1.126$ \\
\hline IDR $2,600,000-5,400,000$ & 287 & 26.9 & 342 & 27.2 & 0.023 & 0.676 & $0.483-0.947$ \\
\hline$>$ IDR 5,400,000 & 68 & 6.4 & 125 & 9.9 & 0.045 & 0.706 & $0.502-0.993$ \\
\hline \multicolumn{8}{|l|}{ Education level } \\
\hline Not graduated elementary school & 102 & 9.6 & 76 & 6.0 & $<0.001$ & 1.00 & \\
\hline Elementary and secondary school & 441 & 41.4 & 490 & 39.0 & $<0.001$ & 0.404 & $0.263-0.619$ \\
\hline High school & 448 & 42.0 & 547 & 43.5 & 0.004 & 0.617 & $0.446-0.854$ \\
\hline University or higher & 75 & 7.0 & 144 & 11.5 & 0.016 & 0.679 & $0.496-0.930$ \\
\hline
\end{tabular}

aOR: Adjusted odds ratio, IDR: Indonesian Rupiah

Table 6. Social determinants of perceiving that TB patient should be shunned

\begin{tabular}{|c|c|c|c|c|c|c|c|}
\hline \multirow[t]{2}{*}{ Characteristics } & \multicolumn{2}{|c|}{ Yes } & \multicolumn{2}{|c|}{ No } & \multirow{2}{*}{$\mathrm{p}$} & \multirow{2}{*}{$\mathrm{aOR}$} & \multirow{2}{*}{$95 \% \mathrm{CI}$} \\
\hline & $\mathrm{n}$ & $\%$ & $\mathrm{n}$ & $\%$ & & & \\
\hline \multicolumn{8}{|l|}{ Family income } \\
\hline$<$ IDR $1,300,000$ & 174 & 32.4 & 457 & 25.6 & 0.089 & 1.000 & \\
\hline IDR $1,300,000-2,599,000$ & 186 & 34.6 & 684 & 38.3 & 0.193 & 0.791 & $0.555-1.126$ \\
\hline IDR 2,600,000 - 5,400,000 & 135 & 25.1 & 494 & 27.7 & 0.023 & 0.676 & $0.483-0.947$ \\
\hline$>$ IDR 5,400,000 & 42 & 7.8 & 151 & 8.5 & 0.045 & 0.706 & $0.502-0.993$ \\
\hline \multicolumn{8}{|l|}{ Education level } \\
\hline Not graduated elementary school & 87 & 16.2 & 91 & 5.1 & $<0.001$ & 1.000 & \\
\hline Elementary and secondary school & 203 & 37.8 & 728 & 40.8 & $<0.001$ & 0.404 & $0.263-0.619$ \\
\hline High school & 212 & 39.5 & 783 & 43.8 & 0.004 & 0.617 & $0.446-0.854$ \\
\hline University or higher & 35 & 6.5 & 184 & 10.3 & 0.016 & 0.679 & $0.496-0.930$ \\
\hline \multicolumn{8}{|l|}{ Residence status } \\
\hline Non permanent resident and foreign & 20 & 3.7 & 30 & 1.7 & & 1.000 & \\
\hline Permanent resident & 517 & 96.3 & 1,756 & 98.3 & 0.470 & 0.810 & $0.458-1.433$ \\
\hline \multicolumn{8}{|l|}{ Health insurance } \\
\hline No insurance & 302 & 56.2 & 1,064 & 59.6 & 0.170 & 1.000 & \\
\hline Askes & 53 & 9.9 & 234 & 13.1 & 0.326 & 0.845 & $0.604-1.183$ \\
\hline Askeskin/Jamkesmas & 70 & 13.0 & 178 & 10.0 & 0.161 & 0.757 & $0.513-1.117$ \\
\hline Jamsostek & 63 & 11.7 & 187 & 10.5 & 0.548 & 1.138 & $0.747-1.734$ \\
\hline Other insurance & 49 & 9.1 & 123 & 6.9 & 0.592 & 0.896 & $0.600-1.338$ \\
\hline
\end{tabular}

aOR: Adjusted odds ratio, IDR: Indonesian Rupiah, Askes: Asuransi Kesehatan (health insurance for state civil servants), Jamkesmas: Jaminan Kesehatan Masyarakat (social health insurance for poor people), Jamsostek: Jaminan Kesehatan Sosial (health insurance for registered formal workers) 


\section{DISCUSSION}

As a "social disease", Government should consider the importance of social determinants and prevent TB spread into uninfected people in the community. It requires a strengthening preventive action in community to resolve this problem. Assessing TB knowledge and perception in community is a prerequisite prior to developing a proper strategy to combat TB in community. This study revealed that current level of knowledge about TB in urban community is good, in general. People may obtain information of TB easily from health care services or television since they live in an urban city with a large access to information.

Communication with trusted persons is a key factor of well deployed information. ${ }^{19}$ Primary health centre (PHC) should provide community health care services instead of relying on in-clinic services by delivering structured, trusted information about TB so that people may the information to their neighbourhood. Otherwise, people may receive bias and incorrect information about TB. Some potential of incorrect information such as TB cause and duration of TB treatment may lead to stigmatization. Misconceptions of treatment and its duration are utmost causes of dropped out cases..$^{10,20}$ Health workers, as a consequence, must provide adequate and proper knowledge of TB to raise community awareness and prevent spreading misconceptions.

People with lower education level tend to lacked of TB knowledge as many studies also reports. ${ }^{21,22}$ Active health promotion is critical. Strengthening promotion through community health workers (CHWs) may resolve this problem instead of waiting people coming to health care services.

People may perceive TB as humiliating or excommunicated disease despite their good level of knowledge. This study brings out issue of disconnection between knowledge and perception. Good level of TB knowledge is not necessarily associated to proper perception of TB. Potential of excommunicating TB patient remains in the community and requires some interventions including strengthening health promotion and optimizing CHWs' role. Unresolved problems of misperceptions causes delayed seeking care of suspected patients. ${ }^{23}$ Suspected patients may resist to seek care or to undergo diagnostic examinations because they worry of being identified as TB patient. Health education can reduce the ignorance that may lead to social stigma, ${ }^{24}$ despite unclear evidence of stigmatization in Jakarta population.

Belonging health saving was not an important social determinant, but having health insurance, Askes in particular, may determine level of knowledge of TB and perception about TB. A high proportion of uninsured household is a potential problem. People much more rely on out-of-pocket spending for their health care, whereas majority of uninsured people does not prepare health savings. A widening coverage of social health insurance may stimulate people to utilize health care service, ${ }^{25,26}$ so that provides positive impacts on TB knowledge and perception.

In conclusion, people in urban area of Jakarta have good level of knowledge about TB, but it does not necessarily lead to proper perception of TB. Age, education level and having health insurance determined level of knowledge, while TB perceptions were determined much more by education level and family income. TB control program should consider these determinants prior to developing a comprehensive strategy. In addition to deploying proper and sufficient information, promoting health saving and reducing financial constraints, such as providing social insurance, will be a critical strategy.

\section{Acknowledgments}

We would thank to all of head of PHC in study area, Ronald S Gunawan and all of enumerators who assisted data collection, as well as Setyawati Budiningsih and Jan Hendrik Richardus who reviewed this articles. This research was supported by Faculty of Medicine, Universitas Indonesia and was funded by research grant from Centre for Integrated Research and Development of Tropical Disease and Infection, Universitas Indonesia.

\section{Conflict of interest}

The authors hereby affirm that there is no conflict of interest in this study.

\section{REFERENCES}

1. Kementerian Kesehatan Republik Indonesia. Strategi nasional pengendalian TB di Indonesia 2010-2014. Jakarta: Kementerian Kesehatan Republik Indonesia; 2011. Indonesian. 
2. World Health Organization. Global tuberculosis control 2011. Geneva: World Health Organization; 2011.

3. Kementerian Kesehatan Republik Indonesia [Internet]. Riset Kesehatan Dasar 2011. [cited 2011 October 15]. Available from: http://www.riskesdas.litbang.depkes.go.id/ laporan2010/reg.php. Indonesian

4. Kementerian Kesehatan Republik Indonesia. Survei prevalensi tuberkulosis 2004. Jakarta: Kementerian Kesehatan Republik Indonesia; 2005. Indonesian.

5. Lönnroth K, Jaramillo E, Williams BG, Dye C, Raviglione M. Drivers of tuberculosis epidemics: the role of risk factors and social determinants. Soc sci med. 2009;68(12):2240-6.

6. Mesfin MM, Newell JN, Walley JD, Gessessew A, Madeley RJ. Delayed consultation among pulmonary tuberculosis patients: a cross sectional study of 10 DOTS districts of Ethiopia. BMC Public Health. 2009;9:53.

7. Finnie RKC, Khoza LB, van den Borne B, Mabunda T, Abotchie P, Mullen PD. Factors associated with patient and health care system delay in diagnosis and treatment for TB in sub-Saharan African countries with high burdens of TB and HIV. Trop Med Int Health. 2011;16(4):394-411.

8. Odusanya OO, Babafemi JO. Patterns of delays amongst pulmonary tuberculosis patients in Lagos, Nigeria. BMC Public Health. 2004;4:18.

9. Ngadaya ES, Mfinanga GS, Wandwalo ER, Morkve O. Delay in tuberculosis case detection in Pwani region, Tanzania. A cross sectional study. BMC Health Serv Res. 2009;9:196.

10. Sevim T, Aksoy E, Ataç G, Ozmen I, Kapakli N, Horzum G, et al. Treatment adherence of 717 patients with tuberculosis in a social security system hospital in Istanbul, Turkey. Int J Tuberc Lung Dis. 2002;6(1):25-31.

11. Garner P, Thaver I. Urban slums and primary health care. BMJ. 1993;306(6879):667-8.

12. World Health Organization. The stop TB strategy: building on and enhancing DOTS to meet the TB-related Millennium Development Goals. Geneva: World Health Organization; 2006.

13. Chakaya J, Uplekar M, Mansoer J, Kutwa A, Karanja $\mathrm{G}$, Ombeka V, et al. Public-private mix for control of tuberculosis and TB-HIV in Nairobi, Kenya: outcomes, opportunities and obstacles. Int $\mathrm{J}$ Tuberc Lung Dis. 2008;12(11):1274-8.

14. Lozano-Fuentes S, Elizondo-Quiroga D, Farfan-Ale JA, Loroño-Pino MA, Garcia-Rejon J, Gomez-Carro S, et al. Use of Google Earth to strengthen public health capacity and facilitate management of vector-borne diseases in resource-poor environments. Bull World Health Organ. 2008;86(9):718-25.

15. Chen SC, Wang JD, Yu JK, Chiang TY, Chan CC, Wang $\mathrm{HH}$, et al. Applying the global positioning system and google earth to evaluate the accessibility of birth services for pregnant women in northern Malawi. J Midwifery Womens Health. 2011;56(1):68-74.

16. Chang AY, Parrales ME, Jimenez J, Sobieszczyk ME, Hammer SM, Copenhaver DJ, et al. Combining Google Earth and GIS mapping technologies in a dengue surveillance system for developing countries. Int J Health Geogr. 2009;8:49.

17. Vine MF, Degnan D, Hanchette C. Geographic information systems: their use in environmental epidemiologic research. Environ Health Perspect. 1997;105(6):598-605.

18. Conroy GC, Anemone RL, Van Regenmorter J, Addison A. Google Earth, GIS, and the Great Divide: a new and simple method for sharing paleontological data. J Hum Evol. 2008;55(4):751-5.

19. Portero NJL, Rubio YM, Pasicatan MA. Socio-economic determinants of knowledge and attitudes about tuberculosis among the general population of Metro Manila, Philippines. Int J Tuberc Lung Dis. 2002;6(4):301-6.

20. Munro S, Lewin S, Swart T, Volmink J. A review of health behaviour theories: how useful are these for developing interventions to promote long-term medication adherence for TB and HIV/AIDS? BMC Public Health. 2007;7:104.

21. Obuku EA, Meynell C, Kiboss-Kyeyune J, Blankley S, Atuhairwe C, Nabankema E, et al. Socio-demographic determinants and prevalence of Tuberculosis knowledge in three slum populations of Uganda. BMC Public Health. 2012;12:536

22. Hargreaves JR, Boccia D, Evans CA, Adato M, Petticrew M, Porter JD. The social determinants of tuberculosis: from evidence to action. Am J Public Health. 2011;101(4):654-62.

23. Baral SC, Karki DK, Newell JN. Causes of stigma and discrimination associated with tuberculosis in Nepal: a qualitative study. BMC Public Health. 2007;7:211.

24. Macq J, Solis A, Martinez G. Assessing the stigma of tuberculosis. Psychol Health Med. 2006;11(3):346-52.

25. Latko B, Temporão JG, Frenk J, Evans TG, Chen LC, Pablos-Mendez A, et al. The growing movement for universal health coverage. Lancet. 2011;377(9784):2161-3.

26. Moreno-Serra R, Smith PC. Does progress towards universal health coverage improve population health? Lancet. 2012;380(9845):917-23. 